\title{
Comparing P-Selectin (CD62P) expression in patients receiving non-leukodepleted versus leukodepleted thrombocyte concentrates
}

\author{
Teguh Triyono ${ }^{1 *}$, Budi Mulyono ${ }^{1}$, Sutaryo ${ }^{2}$, Abdul Salam M. Sofro ${ }^{3}$ \\ ${ }^{1}$ Departement of Clinical Pathology, ${ }^{2}$ Departement of Pediatry, Faculty of Medicine, \\ Universitas Gadjah Mada, Yogyakarta, ${ }^{3}$ Faculty of Medicine, Universitas YARSI, Jakarta, \\ Indonesia
}

DDOI: http://dx.doi.org/10.19106/JMedSci004903201704

\begin{abstract}
Thrombocyte concentrate (TC) transfusion is an important supportive therapy in patients with thrombocytopenia. The risks in platelet transfusions may be related to the content of TC including the contaminant leukocytes. The aim of this study was to assess the risk of increased level of P-Selectin (CD62P) expression of non-leukodepleted TC transfusions. This was a quasi-experimental study. Subjects were children patients aged 1-18 years who received a non-leukodepleted or a leukodepleted TC transfusions. Comparison of the proportion of increased expression of CD62P in both groups expressed as relative risk. The subjects consisted of 51 patients who received non-leukodepleted and 52 patients who received leukodepleted TC transfusions. The risk of increased expression of CD62P in patients receiving non-leukodepleted TC transfusions were $2.38(95 \% \mathrm{Cl}: 1.60-3.53)$ times higher than those who received leukodepleted TC. Non-leukodepleted have significant higher risks of increased CD62P expression than leukodepleted TC transfusions.
\end{abstract}

\section{ABSTRAK}

Transfusi thrombocyte concentrate (TC) merupakan terapi pendukung yang penting pada pasien yang mengalami trombositopenia. Risiko yang terjadi dapat terkait dengan komponen yang terkandung dalam TC termasuk adanya lekosit kontaminan. Penelitian ini bertujuan untuk menilai risiko berupa kejadian peningkatan ekspresi $P$-selectin (CD62P) pada transfusi TC non-lekodeplesi. Penelitian ini merupakan penelitian eksperimental semu. Subjek penelitian adalah pasien anak usia 1-18 tahun yang mendapat transfusi TC non-lekodeplesi dan lekodeplesi. Perbandingan proporsi peningkatan ekspresi CD62P pada kedua kelompok dinyatakan dalam risiko relatif. Subjek terdiri dari 51 pasien yang mendapatkan transfusi TC non-lekodeplesi dan 52 pasien yang mendapatkan transfusi TC lekodeplesi. Risiko peningkatan ekspresi CD62P pada pasien yang mendapatkan transfusi TC non-lekodeplesi adalah 2,38 (95\% Cl:1,60-3,53) kali lebih tinggi dibandingkan yang mendapatkan transfusi TC lekodeplesi. Transfusi TC non-lekodeplesi memiliki risiko yang lebih tinggi bermakna dibandingkan TC lekodeplesi.

Keywords: thrombocyte concentrate - transfusion - CD62P expression thrombocytopenia - adverse effect 


\section{INTRODUCTION}

Globally, total blood donations are approximately 107 million units annually, which is almost fifty percents collected in high-income countries. In Indonesia 4,644,863 units of blood products were processed in 2014, which were consisted of $16.18 \%$ whole blood and $83.82 \%$ components. From those components, $58 \%$ were packed red cells (PRC), 22\% were fresh plasma, 13\% were thrombocyte concentrate (TC), $6 \%$ were fresh frozen plasma (FFP), $0.18 \%$ were washed erythrocyte, $0.65 \%$ were cryoprecipitate, and $0.17 \%$ were apheresis platelet. ${ }^{1}$ At Dr. Sardjito General Hospital, Yogyakarta, approximately 36,000 units of blood components transfusion are registered annually. The increase of TC use has been noted from $29.52 \%$ in 2011 to $37.2 \%$ in 2015 . Pediatry ward was the largest TC user, and there has been a steady increased of TC use from $51.20 \%$ in 2011 to $67.01 \%$ in 2015. ${ }^{2}$

Platelet transfusion is associated with post-transfusion reaction including allergic reaction and febrile non-hemolytic reaction. ${ }^{3}$ To reduce the risk of leukocyte-associated transfusion adverse event, blood component should be leukoreduced before usage. ${ }^{4}$ So far, there is little concern about leukocyte contaminants within blood component especially in developing countries. One of many methods described to eliminate thrombocyte transfusion reaction is by doing TC leukodepletion. Leukodepletion is a procedure to remove leukocyte contaminants present within blood component, using a specific filter. $^{5}$

Nielsen et $a l .{ }^{6}$ reported accumulation of chemical mediators as the result of leukocyte intracellular granule release during blood component storage (PRC or TC) such as histamine, eosinophil cationic protein, eosinophil protein $\mathrm{X}$, myeloperoxidase, and plasminogen activator inhibitor-1. Leukocyte could affect the function of platelets by releasing any chemical substances for example cathepsin $\mathrm{G}$, reactive oxygen species, nitric oxide, ${ }^{7,8}$ and myeloperoxidase (MPO). ${ }^{6}$

Myeloperoxidase is originally an enzyme stored inside the granule of polymorphonuclear cell (PMN), its detectable level in circulation reflects the degranulation of PMN and PMN cells that undergo necrosis during blood component storage also produceit. This enzyme is secreted along with other biochemical substances like protease and peroxydase to surrounding extracellular environtment. ${ }^{9}$ MPO-induced platelet activation is marked by increasing expression of P-selectin (CD62P) and Platelet Endothelial Cell Adhesion Molecule-1(PECAM-1). ${ }^{10-12}$ This study was aimed to compare the CD62P expression in patients receiving non-leukodepleted versus leukodepleted thrombocyte concentrates.

\section{MATERIALS AND METHODS}

\section{Subjects}

Study subjects of this research were pediatric patients receiving transfusion of either non-leukodepleted or leukodepleted TC during their care in Estella ward Dr. Sardjito General Hospital, Yogyakarta. The subjects were selected in consecutive sampling basis according to inclusion and exclusion criteria. Randomization could not be performed properly because of a limitation in preparing leukodepleted TCs. Inclusion criteria of this study were all pediatric patient age 1-18 years old diagnosed with malignancy and indicated to receive platelet transfusion. The study subjects would be excluded from research if he had bleeding manifestation, DIC, hypersplenisms, fever, receiving antipiretic or antithrombotic therapy or other blood component transfusions. Study subjects were categorized into two groups, first group received non-leukodepleted TC and another 
grup received leukodepleted TC transfusion. Protocol of this study has been approved by the Medical and Health Research Ethics Committee of Faculty of Medicine, Univesitas Gadjah Mada, Yogyakarta. Leukodepleted thrombocyte concentrates were plateletpooled (2-4 units) derived from whole blood with CPDA1 processed using PRP method and filtered to remove leukocyte contaminants before stored in agitator at $20-24{ }^{\circ} \mathrm{C}$ for maximum 5 days. Non-leukodepleted thrombocyte concentrates were produced using the same process without undergone leukocyte filtration.

\section{Measurement of CD62P expression using flowcytometry method}

The method applied in this research refered to previous method developed by
Kim and Lim, ${ }^{13}$ which minimalize platelet activation artificially, eliminating the need of centrifugation for washing and fixation before labelling and simultaneously label monoclonal antibody to the patient platelets. CD62P expression was measured by flowcytometry method using monoclonal antibody antiCD62P-FITC against whole blood sample without addition of agonist (ADP). The measurement was conducted on blood sample before and 1 hour after TC transfusion (pre vs. post-transfusion). For analytical purpose, gates were made in predetermined platelet area with addition of anti-CD41-PE (FIGURE 1). Data were presented as platelet percentage that positively expressed CD62P.
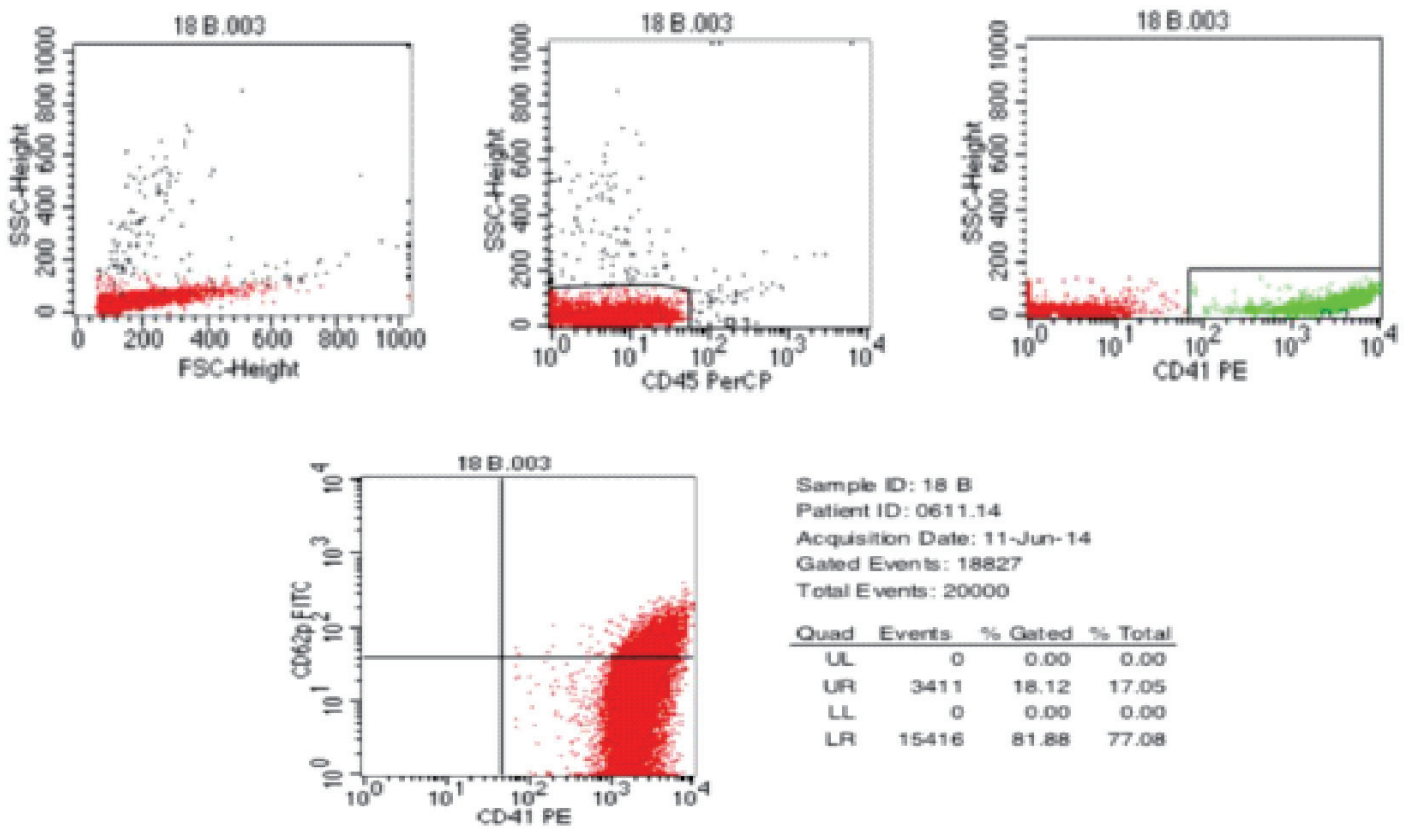

FIGURE 1. Dot plot and statistic quadrans of CD62P measurement 


\section{Data analysis}

Subject characteristics was presented descriptively. The percentage of platelet (\%) that expressed CD62P was presented as mean value. The comparison of increased CD62P expression in both groups was presented as relative risk. Statistical analysis was performed at significance value $\mathrm{p}<0.05$ with confidence interval of $95 \%$.

\section{RESULTS}

Total subjects enrolled in this study were 103 patients, divided into 2 groups; first group consist of 51 patients receiving non-leukodepleted TC and another group of 52 patients receiving leukodepleted TC transfusion. Subject characteristics were summarized in TABLE 1. Overall, there were no statistically significant difference $(p>0.05)$ between two groups in term of gender, age, body weight, height, body surface area (BSA) and body mass index (BMI).

TABLE 1. Characteristics of subjects

\begin{tabular}{lccc}
\hline \multicolumn{1}{c}{ Characteristic } & $\begin{array}{c}\text { Non-leukodepleted } \\
(\mathbf{n}=\mathbf{5 1})\end{array}$ & $\begin{array}{c}\text { Leukodepleted } \\
(\mathbf{n}=\mathbf{5 2})\end{array}$ & $\mathbf{p}$ \\
\hline Gender & & & \\
Male & $32(62.7 \%)$ & $30(57.7 \%)$ & 0.600 \\
$\quad$ Female & $19(37.3 \%)$ & $22(42.3 \%)$ & \\
Age (mean \pm SD year) & $8.69 \pm 4.83$ & $9.93 \pm 5.10$ & 0.209 \\
$1-5$ & 16 & 12 & \\
$5-10$ & 17 & 17 & \\
$10-14$ & 7 & 6 & \\
$14-18$ & 11 & 17 & 0.847 \\
Weight $($ mean $\pm \mathrm{SD} \mathrm{kg})$ & $26.12 \pm 15.84$ & $26.67 \pm 12.84$ & 0.279 \\
Height $($ mean $\pm \mathrm{SD} \mathrm{m})$ & $1.22 \pm 0.28$ & $1.28 \pm 0.29$ & 0.491 \\
BSA $\left(\right.$ mean $\left.\pm \mathrm{SD} \mathrm{m}{ }^{2}\right)$ & $0.925 \pm 0.379$ & $0.975 \pm 0.354$ & 0.259 \\
BMI $\left(\right.$ mean $\left.\pm \mathrm{SD} \mathrm{kg} / \mathrm{m}^{2}\right)$ & $16.048 \pm 4.10$ & $15.279 \pm 2.64$ & \\
\hline
\end{tabular}

In this study, CD62P expression on platelet was measured from patient venous blood sample before and 1 hour after TC transfusions. Mean expression of CD62P before transfusion was not statistically significant difference between two groups i.e. $25.42 \pm 19.52 \%$ in non-leukodepleted group and 27.16 $\pm 10.31 \%$ in leukodepleted group respectively $(\mathrm{p}>$ $0.05)$. On the contrary, there was statistically significant difference in mean expression of post-transfusion CD62P ( $\mathrm{p}<0.05$ ), wich the group receiving non-leukodepleted TC expressed higher level (35.85 \pm 20.31\%) than the group receiving leukodepleted TC transfusion (24.12 $\pm 7.16 \%$ ). Mean expression of post-transfusion CD62P in group receiving non-leukodepleted TC post- transfusion was increased than pre-transfusion, meanwhile in leukodepleted group, it was slightly decreased as seen in TABLE 2 . 
Triyono et al., Comparing P-Selectin (CD62P) expression in patients receiving non-leukodepleted versus leukodepleted thrombocyte concentrates

TABLE 2. Mean expression of pre and post-transfusion CD62P

\begin{tabular}{cccc}
\hline Group & $\begin{array}{c}\text { Non-leukodepleted } \\
(\mathbf{n = 5 1 )} \\
\%\end{array}$ & $\begin{array}{c}\text { Leukodepleted } \\
(\mathbf{n}=\mathbf{5 2}) \\
\mathbf{\%}\end{array}$ & $\mathbf{p}$ \\
\hline Pre-transfusion & $25.42 \pm 19.52$ & $27.16 \pm 10.31$ & 0.574 \\
Post-transfusion & $35.85 \pm 20.31$ & $24.12 \pm 7.16$ & 0.000 \\
\hline
\end{tabular}

Relative risk of increased $\mathrm{CD} 62 \mathrm{P}$ expression in patients receiving nonleukodepleted TC compared to leukodepleted group was presented in the TALE 3. It was seen that the increased CD62P expression was 2.38 times higher in the group receiving non-leukodepleted TC than leukodepleted TC transfusions.

TABLE 3. Relative risk of increased CD62P expression in non-leukodepleted group

\begin{tabular}{lcccc}
\hline Group & Increment $(+)$ & Increment (-) & Total & p \\
\hline Non-leukodepleted & 42 & 9 & 51 & \\
Leukodepleted & 18 & 34 & 52 & 0.000 \\
Total & 60 & 43 & 103 & \\
\hline
\end{tabular}

Relative risk $=2.38 ;(95 \% \mathrm{CI}=1.60-3.53)$

\section{DISCUSSION}

The increased expression of posttransfusion $\mathrm{CD} 62 \mathrm{P}$ was greater in the group receiving non-leukodepleted TC than leukodepleted TC probably caused by addition effects of pretransfusion activated donor platelets or the effect of increased level of MPO in transfused TCs. Nomura et al. ${ }^{14}$ have conducted a research with transfusion of 100 TCs involved 28 hematologic and non-hematologic malignancy patients, it was concluded that platelet CD62P expression was diminished significantly after leukocyte filtration process or leukodepletion.

There were some markers to evaluate platelet activation such as $\beta$-Thyroglobulin ( $\beta$ TG), Glycoprotein-1 $\beta$ (GPIB/CD42), platelet aggregation test or GPIIb/IIIa (CD41), soluble $\mathrm{P}-$ selectin, surface P-selectin (CD62P), and among them CD62P is the best marker. ${ }^{15-17}$ CD62P also known as $\alpha$-granule platelet membran protein-140 (GMP-140), expressed on the surface membrane during platelet activation, but remain undetectable in resting platelets. CD62P reported to be expressed rapidly on the surface membrane when platelet is activated. ${ }^{18} \mathrm{CD} 62 \mathrm{P}$ is the most sensitive and specific marker which reflects activation of platelets. Among other activated thrombocyte surface marker, CD62P expression shows the most significant difference between activated and resting platelet state..$^{18,19}$

There was a correlation between P-selectin expression and platelet survival after transfusion, stronger expression of P-Selectin on the platelet surface, associated with easier destruction of platelet after being transfused. ${ }^{18,19}$ After activation, platelets will release proinflammatory chemokine, cytokine and adhesion molecule appear onto its surface, including CD62P and CD40 ligand (CD40L). Interaction between platelet and neutrophyl triggers recruitment of neutrophyles to the inflammed tissue, activates the neutrophyles 
and it contribute toward host immunity and thrombosis process. Human neutrophil $\alpha$-defensins (HNPs) consist of 50\% protein from azurophilic granules. It can be released from azurophilic granule into extracellular environtment after PMN cell activation and then undergo degranulation, leakage, cell death and lysis during inflammation. ${ }^{20}$

Clinical relevance of CD62P expression level to predict in vivo platelet behaviour after transfusion is still debatable and not fully understood. It is partly based on fact that dynamicity of platelet and loss of CD62P surface protein. ${ }^{21}$ There was evidence that P-selectin level increased during storage, whereas its activatability undergo reduction. ${ }^{22}$ Increased level of CD62P significantly unrelated to body mass index (BSA), carotid intima media thickness and inflammatory mediator (CRP). ${ }^{17}$

\section{CONCLUSION}

In conclusion, non-leukodepleted have significant 2.38 times higher risk of increased post-transfusion $\mathrm{CD} 62 \mathrm{P}$ expression than leukodepleted TC transfusions.

\section{ACKNOWLEDGEMENT}

We wish to thank dr. Eddy Supriyadi, Sp.A(K)., Ph.D. for valuable assistance in preparing the subjects.

\section{REFERENCES}

1. Kemenkes RI. Laporan hasil UTD tahun 2014: Pelayanan darah di Indonesia. Jakarta: Kementrian Kesehatan Republik Indonesia, 2015.

2. UPTD RSUP Dr. Sardjito. Laporan pengeluaran darah dan rekapitulasi pengeluaran darah. Yogyakarta 2011 dan 2015. Yogyakarta: RSUP Dr. Sardjito, 2015.
3. Kaufman RM, Djulbegovic B, Gernsheimer T, Kleinman S, Tinmouth AT, Capocelli KE, et al. Platelet transfusion: A clinical practice guideline from the AABB. Ann Intern Med 2015; 162 (3): 205-13. http://dx.doi. org/10.7326/M14-1589.

4. Xie ZT, Chen C, Zhang SH, Yang HM, Tao $Z H$. Effect of leukocyte filtration on the P-selectin expression of apheresis platelets. Genet Mol Res 2015; 14(2):5979-85. http:// dx.doi.org/10.4238/2015.June.1.15.

5. Sharma, RR., Marwaha, N. Leukoreduced blood components: Advantages and strategies for its implementation in developing countries. Asian J Transfus Sci 2010; 4(1):3-8. http:// dx.doi.org/10.4103/0973-6247.59384

6. Nielsen HJ, Reimert CM, Pedersen AN, Brunner N, Edvardsen L, Dybkler L, et al. Time-dependent, spontaneous release of white cell and platelet-derived bioactive substances from stored human blood. Transfusion 1996; 36(11-12): 960-5.

http://dx.doi.org/10.1046/j.15372995.1996.36111297091738.x

7. Faraday N, Scharph RB, Doddo JM, Martinez EA, Rosenfeld BA, Dorman T. Leukocytes can enhance platelet-mediated aggregation and thromboxane release via interaction of P-selection glycoprotein ligand 1 with P-selectin. Anesthesiology 2001; 94: 145-51. http://dx.doi.org/10.1097/00000542200101000-00025

8. Faint RW. Platelet-neutrophil interactions: their significance. Blood 1992; 6(2):83-91. http://dx.doi.org/10.1016/0268-960X(92) 90010-N

9. McFaul SJ, Corley JB, Mester CW, Nath J. Packed blood cells stored in AS-5 become proinflammatory during storage. Transfusion 2009; 49(7):1451-60.

http://dx.doi.org/10.1111/j.1537-2995. 2009. 02158.x 
10. Kolarova H, Klinke A, Kremserova S, Adam M, Pekarova M, Baldus S, et al. Myeloperoxidase induces the priming of platelets. Free Radic Biol Med 2013; 61:357-69. http://dx.doi.org/10.1016/j. freeradbiomed.2013.04.014

11. Eiserich JP, Baldus S, Bernnan ML, Ma W, Zhang C, Tousson A, et al. Myeloperoxidase a leukocyte-derived vascular NO oxidase. Science 2002; 296(5577):2391-4. http://dx.doi.org/10.1126/science.1106830

12. Baldus S, HeitzerT, EiserichJP,LauD, Mollnau $\mathrm{H}$, Ortak M, et al. Myeloperoxidase enhances nitric oxide catabolism during myocardial ischemia and reperfusion. Free Radic Biol Med 2004; 37(6):902-11. http://dx.doi. org/10.1016/j.freeradbiomed.2004.06.003

13. Kim SW, Lim YA. Establishment of reference values for platelet activation markers by flowcytometry. Korean J Lab Med 2006; 26(5):323-8.

http://dx.doi.org/10.3343/kjlm.2006.26.5.323

14. Nomura S, Okamae F, Abe M, Hosokawa M, YamaokaM,OhtaniT,etal.Plateletsexpressing P-selectin and platelet-derived microparticles in stored platelet concentrates bind to PSGL1 on filtrated leukocytes. Clin Appl Thromb Hemost 2000; 6(4):213-21. http://dx.doi. org/10.1177/107602960000600406.

15. Plaza EM, Cespedes P, Fernandez H, Sanchez-Guiu MI, Egea JM, Vicente V, et al. Quality assessment of buffy-coat-derived leukodepleted platelet concentrates in PASplasma, prepared by the Orbi Sac or TACSI automated system. Voxsanguinis 2013; 106(1):1-7.

16. Bashir S, Nightingale MJ, Cardigan, R. Ensuring that blood transfusion sets an effective dose of functional blood components. Transfus Med 2013; 23(4):22630. http://dx.doi.org/10.1111/tme.12045
17. Nagy BJ, Debreceni IB, Kappelmayer J. Flowcytometry in the clinical laboratory flowcytometric investigation of classical and alternative platelet activation. EJIFCC 2012; 23(4):1-11.

18. Vetlesen A, Holme PA, Lyberg T, KjeldsenKragh J. Recovery, survival, and function of transfused platelets and detection of platelet engraftment after allogeneic stem cell transplantation. Transfusion 2012; 52(6): 1321-32.

http://dx.doi.org/10.1111/j.1537-2995. 2011. 03442.x.

19. Ritchie JL, Alexander HD, Rea IM. Flowcytometry analysis of platelet P-selectin expression in whole blood-methodological considerations. Clin Lab Haematol 2000; 22(6):359-63. http://dx.doi.org/10.1046/ j.1365-2257.2000.00339.x

20. Horn M, Bertling A, Brodde MF, Muller A, Roth J, Van Aken $\mathrm{H}$, et al. Human neutrophil alpha-defensins induce formation of fibrinogen and thrombospondin-1 amyloid-like structures and activate platelets via glycoprotein IIb/IIIa. J Thromb Haemost 2012; 10(4):647-61. http://dx.doi. org/10.1111/j.1538-7836.2012.04640.x.

21. Levin E, Jenkin C, Culibrk B, Issa G, Maria IC, Serrano K, et al. Development of a quality monitoring program for platelet components: a report of the first four years' experience at Canadian Blood Services. Transfusion 2012; 52(4):810-18.

http://dx.doi.org/10.1111/j.15372995.2011.03402.x.

22. Panzer S, Jilma P. Methods for testing platelet function for transfusion medicine. Voxsanguinis 2011; 101(1):1-9. http://dx.doi. org/10.1111/j.1423-0410.2011.01467.x 